\title{
Negotiating Multiple Identities in a Queer Vietnamese Support Group
}

\author{
Gina Masequesmay, $\mathrm{PhD}$ \\ California State University, Northridge
}

SUMMARY. My participant-observation with Ô-Môi, a support group for Vietnamese lesbians, bisexual women and female-to-male transgenders, and interviews with members, focusing on how different identity issues are negotiated, suggest that despite Ô-Môi's claim of supporting its members' multiple marginalized identities, group processes in everyday pragmatic interactions construct a hierarchy that centers and normalizes experiences of bilingual Vietnamese lesbians. This renders the marginalization of bisexual women, transgender men, and Vietnamese/English monolingual members. Using the concept of "identity work" to examine the intersection of race/ethnicity, class, and gender/sexuality as everyday (counter)hegemonic processes, I discuss how organizational

Correspondence may be addressed: Department of Asian American Studies, California State University, Northridge, 18111 Nordhoff Street, Northridge, CA 913308251 (E-mail: Gina.Masequesmay@csun.edu).

This paper is based on the data collected by the author for her dissertation, work supported by the American Sociological Association's Minority Fellowship Program, which was funded by the National Institute of Mental Health. None of this work would be possible without the support, encouragement and cooperation of the women and men who were in and affiliated with Ô-Môi. The author would also like to thank her editors for their support and reviewers for their comments.

[Haworth co-indexing entry note]: "Negotiating Multiple Identities in a Queer Vietnamese Support Group." Masequesmay, Gina. Co-published simultaneously in Journal of Homosexuality (Harrington Park Press, an imprint of The Haworth Press, Inc.) Vol. 45, No. 2/3/4, 2003, pp. 193-215; and: Queer Theory and Communication: From Disciplining Queers to Queering the Discipline(s) (ed: Gust A. Yep, Karen E. Lovaas, and John P. Elia) Harrington Park Press, an imprint of The Haworth Press, Inc., 2003, pp. 193-215. Single or multiple copies of this article are available for a fee from The Haworth Document Delivery Service [1-800-HAWORTH, 9:00 a.m. - 5:00 p.m. (EST). E-mail address: docdelivery@haworthpress.com].

http://www.haworthpress.com/store/product.asp?sku=J082

(C) 2003 by The Haworth Press, Inc. All rights reserved.

10.1300/J082v45n02_09 
structure, discourse resources, and personal politics orient and mold members' talk and interactions leading to normalization and/or marginalization of certain groups' experiences. [Article copies available for a fee from The Haworth Document Delivery Service: 1-800-HAWORTH. E-mail address: $<$ docdelivery@haworthpress.com>Website: <http://www.HaworthPress.com> (c) 2003 by The Haworth Press, Inc. All rights reserved.]

KEYWORDS. Identity work, lesbian, multiple identities, queer, support group, Vietnamese American

Recent years have witnessed a proliferation of ethnic-specific queer (short for LGBT or lesbian/gay/bisexual/transgender) support groups in the Los Angeles region, the largest and new mecca for immigrants in the United States (Waldinger \& Bozorgmehr, 1996). As a result of an influx of immigrants from Latin America and Asia since 1965, the Los Angeles region has become the new capital of immigrants, surpassing New York in the percentage of foreign-born, 36.2\% to 29.4\% (http://www.census.org, 2000). This dramatic demographic shift creates new ethnic enclaves in addition to the traditional Chinatowns and Little Tokyos (e.g., Little Saigon for Vietnamese; Monterey Park for Chinese; Koreatown for Koreans; Little Phnom Penh for Cambodians; Thai Town for Thai). Because of the high concentration of Asian immigrants in Los Angeles and Orange Counties, a critical mass makes it possible for different Asian ethnic groups and gender groups to splinter from larger co-gender, queer, Asian panethnic groups. Whereas in the past queer Asian Americans were ecstatic to have an Asian Pacific Islander (API) queer organization in Los Angeles (i.e., from Asian/Pacific Lesbians and Gays), queers in the mid-1990s not only want an API queer women's group, they want ethnic specific ones as well (e.g., Gay Vietnamese Alliance, LAAPIS). Ô-Môi ("oh-moy"), a support group for Vietnamese lesbians, bisexual women and female-to-male (FTM) transgenders, is one such group.

To say that demographic change results in the proliferation of ethnic-specific queer support groups is an incomplete story, however. Testimonies of founding members of such groups suggest that the reason for splintering also has to do with members being unsatisfied with existing groups (i.e., single identity based organizations) that are not addressing their needs. Mainstream queer organizations, for example, are predominantly white and male. Queer women and racial minorities often feel that they are a minority within these queer organizations because of the racism and sexism that they encounter. Mainstream organizations are often ignorant about minority issues, and the concerns of these racial and gender minorities are often not addressed or are downplayed (Anzaldùa, 1990; Wat, 2002). Many racial minorities and women, therefore, splinter off to form their own organizations where they believe a focus on gender and/or race will better suit their needs. Within the 
Asian panethnic women's organizations, ethnic differences also surface, prodding members to found more ethnic-specific, queer female organizations that better understand their unique multiply marginalized experiences and needs. Queer female Vietnamese in late 1990s Los Angeles wanted a space where they did not have to explain and justify themselves to white folks, straight people, men, and those people who do not understand the Vietnamese refugee background.

Ô-Môi and similar groups that have emerged in the 1990s are responding to a common theme of alienation experienced in (post)modern life (for a related theoretical overview and summary on identity, see Masequesmay, 2001). For immigrants and refugees, the disconnections and uprootedness seem even more salient as these "strangers" (Simmel, 1988) strive to re-establish organic ties. Living in the U.S., where race, class, gender and sexuality organize society into a matrix of hierarchies (Collins, 1990), immigrants and refugees of racial minority status, from lower economic classes, who are women or transgender, and who have queer sexual identities have multiple hurdles to overcome. Because of these multiple dimensions of inequality that racialize, genderize, sexualize and ethnicize "the Other," Vietnamese queer females organize themselves around such marginalized statuses or identities to resist these oppressive forces; that is, the structures of inequality based on race, class, gender, and sexuality exist as social processes that suppress and exploit marginalized identities. Where there is oppression, we also witness resistance. Thus, in the 1990s, as was also seen in previous decades, people have organized around marginalized identity/ies as a means of resistance. Identity-based organizations can be seen as refuge, safe space, and even virtual home (e.g., Ô-Môi listserv) for people with marginalized identities. In short, people with multiple marginalized identities often respond by forming multiple-identity-based organizations.

This paper explores how one such multiple-identity-based organization struggles to support its members. I examine the following questions: Under what conditions are different identity issues negotiated among members? How does Ô-Môi support its members? Since Ô-Môi is based on multiple marginalized identities, I first turn my attention to the literature on multiple identities and resistance. Then, I provide background information about Ô-Môi and my entrée into the organization. Given the allotted space for this paper, I limit my focus to a few patterns of identity work discovered at Ô-Môi that challenge old hierarchies as well as create new ones. Finally, I conclude with a discussion of identity work at Ô-Môi as part of the process of becoming gendered and sexualized ethnic Americans in capitalist America.

\section{IDENTITY WORK AS EVERYDAY (COUNTER)HEGEMONIC PROCESSES}

This study is about marginalized social identities and how people make sense of their marginalized statuses and deploy these notions of identity to 
draw boundaries between insiders and outsiders in an effort to normalize their experiences and bond with others like themselves. Specifically, my study focuses on a group of queer Vietnamese women and transgendered men who are expanding their circles of friendships and acquaintances to create a network of resources to empower and support one another. As Ô-Môi is an organization that is formed around ethnic, gender, and sexual identities, managing diversity within the group becomes a dominant theme in group interactions. Identity issues are negotiated and prioritized among members of diverse gender and sexuality to arrive at a sense of commonality and unity. My study records the processes of how these different issues of identity are negotiated in a group organized around multiple marginalized identities. I examine the uses of identity in interaction, the contexts in which they are deployed, and the degrees of supportive effects of these interactions on group members.

The growing literature on identity reflects the increasing significance of its current role (Calhoun, 1994; Cheney, 1991; Dunn, 1998; Giddens, 1992). With the successes of identity-based movements since the 1960s that fortify identity politics (e.g., the African American civil rights movement, women's movement, and gay and lesbian movement), identity-based policies have come to affect all aspects of life and institutionalized gender, ethnic, racial and sexual identities (Dunn, 1998; Gubrium \& Holstein, 2001). In the mid-1980s, "identity" became a buzzword in academe, in disciplines ranging from the humanities to the social sciences. According to historian Philip Gleason (1983), references to the concept of identity were rare prior to the 1950s. Since then, the concept has become both ubiquitous and elusive in academic discussions because of variegated conceptualizations in research that attempt to address the growing significance of the politics of identity in social life. By the late 1990 s, the overzealous use of this concept led to doubts about its analytical worth. Some scholars advocate using more specific terms to describe what identity does or signifies (Brubaker \& Cooper, 2000). This is part of my task here-to explore how notions of "identity" are used in interaction and how its meanings are understood and negotiated among members of a group that is organized around marginalized identities; that is, I am not concerned with identity as an analytical concept per se. Rather, I am interested in exploring how people understand and use identity in interaction to establish commonality and differences between themselves and others. Rather than identity, I will be examining "identity work."

Studies on race, ethnicity, gender, and sexuality emphasize that identity issues and the everyday evoking of racial, ethnic, sexual, and gender identities are intricately intertwined with ongoing efforts to reinforce or challenge institutions of race, ethnicity, gender, and sexuality (Butler, 1990; Gagne \& Tewksbury, 1998; Omi \& Winant, 1994; West \& Zimmerman, 1987). Because these institutions are based on patriarchy, heterosexism, and white supremacy, subordinate racial, ethnic, gender and sexual statuses are marginalized and stigmatized by the dominant white, straight male-identified structure (Collins, 
1990; hooks, 1984). Minority identities are constructed as "Others" in contrast to the centered white, straight, male image. Racial, ethnic, gender, and sexual categories then become tools to control segments of the population. They are impositions by those in power to maintain the system of hierarchy ideologically and materially (Pfohl, 1994; Wittig, 1992) and are also means by which minority groups organize and mobilize to fight against oppression and exploitation (Espiritu, 1992; Omi \& Winant, 1994). In short, identity markers help people navigate through the changing landscape of sexual, ethnic, racial, and gender politics, sometimes as a means of resistance and liberation, and sometimes as a means of imposition and control (Rust, 1996; Esterberg, 1997).

Using Michael Burawoy's extended case method (1991), I apply my ethnographic work at Ô-Môi as a case study to understand how issues of racial, sexual, ethnic, and gender domination and resistance are played out at the everyday level. Ô-Môi, as a group organized around multiple marginalized identities, is an opportune site at which to see how resistance and conformity to hegemonic constructions of race, gender-sex, and sexuality are played out at the level of everyday interaction and, particularly, to note in-group tensions in resisting or reinforcing hegemony.

Although most studies on race, gender, and sexuality have looked at identity groups as attempts at resistance to cultural domination (e.g., Espiritu, 1992; Taylor \& Whittier, 1992), they examine resistance at the level of a single identity (e.g., Asian or lesbian), not multiple identities. My study of Ô-Môi contributes rich details on the "how so" question of resistance in a multiple-identities-based group. As a support group for lesbians, bisexual women and FTM transgenders of Vietnamese heritage, Ô-Môi is resisting hegemony by providing a space for people to normalize and celebrate their otherwise marginalized ethnic, gender, and sexual identities. Ô-Môi space allows members to redraw boundaries and contest negative connotations and meanings of their sexual, gender and racial/ethnic identities. I refer to this kind of work by members as identity work. Identity work is a process of interaction in which racial, sexual, gender, and/or ethnic identity are evoked for the purpose of creating a sense of commonality or for the purpose of drawing differences (Masequesmay, 2000). Furthermore, identity work refers to attempts to allocate ideological and/or material resources along the social boundaries of race, class, gender, and sexuality. For example, hegemonic sexuality discourse may be used in identity work to reify the binary gender system as opposed to offering a more fluid view of sexual and gender possibilities. Additionally, counterhegemonic discourse in sexual identity work, for example, can redefine marriage to include same-sex partners for inheritance rights.

In an earlier study at an Asian/Pacific Islander AIDS organization called APAIT (Masequesmay, 2000), I argued that everyday identity work (e.g., sexual, gender, racial, ethnic) at APAIT was mediated primarily by the funding structure, the organization's objective of doing API AIDS work, the pragmatic tasks at hand, and members' politics. These contextual influences interacted 
with the level of political consciousness of the staff and volunteers in a way that led to the prevalence of "racial identity work" stressing commonality. As a result, there was a pattern of identity work by staff and volunteers that essentialized the API category rather than dismantle it, despite members' conscious critique of the racial imposition. The data imply that everyday identity work that is pragmatic for people to bond interactionally has political consequences because its patterns of interactions are largely mediated by economic and racial structures that reify race. Often, this everyday racial identity work subsumes the deconstructive politics of queer activist staff and volunteers; that is, despite staff and volunteers' consciousness about deconstructing racial, gender and sexual categories, their regular organizational duties require that they stress racial commonality and, in effect, reify race. Everyday identity work can thus be seen as everyday identity politics (the racial project; doing gender; queering; ethnicizing) that can challenge or reinforce the matrix of hierarchies. The next section elaborates on the concepts employed in this study: identity work, hegemonic practices of everyday life, and marginalization.

\section{Definition of Concepts}

(A) The everyday construction and negotiation of identities that I have shortened to identity work includes:

1. Verbal doing of identity/ies. Evoking an identity or identities (sexual, ethnic, gender, racial) in conversation as a means to connect with others. At the same time, those not sharing the identity/ies are excluded. For example, to mention bisexuality in a monosexual context means challenging the binary understanding of sexuality.

2. Acting out an identity/ies in gesture and/or appearance. Performing identity/ies in interaction as a means to connect to others with the same identity/ies. Those not sharing the identity/ies are excluded. For example, one lesbian describes having "a certain swagger when she walks" (Esterberg 1996) as acting out her lesbianism to attract other lesbians.

3. Positive utterance of an identity/ies to include and affirm an identity/ies whereas no or negative utterance would exclude and may marginalize identity/ies. Lesbian, bisexual, transgender identities are often talked about negatively in straight settings. Positive utterances serve to affirm otherwise stigmatized and invisible identity/ies.

4. Negotiating meanings of identity/ies to reinforce or challenge dominant discourses about such identities. For example, the argument that one is born either straight or gay can be seen as belonging to the dominant binary gender-sex discourse that limits human potential to being homosexual or heterosexual. Bisexuals are left out in this discursive legitimization process. Viewing sexuality as fluid challenges this binary thinking. 
5. Extending on the fourth idea about negotiating meanings of identity/ies, a group could assert specific meanings of an identity for members and thus set strict norms and control over what members can come out as and how members can "do identity/ies." For example, Ô-Môi has limited their support of transgenders to only FTM transsexuals who identify as straight. Those who do not conform to this trajectory are excluded from the group support. Those who are just coming out and are confused about their gender identities feel pressured to come out as straight FTM transsexuals lest they invite further marginalization as "unknown."

These are five ways in which identity work is done. By conceptualizing identity work as a process, I allow room for multiple identities to interact in discursive and non-discursive practices where one or a few identities issues may dominate others or all may weigh equally. In addition, as discussed above, identity work has political significance in challenging or reinforcing the hegemony of race, gender, and sexuality.

(B) I use Steven Pfohl's modified conceptualization of Gramsci's term "hegemony" to discuss the "hegemonic practices of everyday life" (1994, p. 416). According to Pfohl, everyday rituals are hegemonic when they reinforce the structures of domination and make what we do appear natural and commonsensical. Hegemony limits our moral imagination and makes other ways of interpreting the world unthinkable. Hence, when we do not question and challenge the status quo but instead partake in and comply with our own domination via ritualistic practices, our consent to rule is realized and hegemony asserts itself. I discuss the patterns of identity work as hegemonic or counterhegemonic, according to whether the practices of identity constructions are reproducing the status quo or challenging it, where the status quo is the dominant ideology that marginalizes racial minorities, gender, and sexual minorities.

(C) I use the term marginalization to refer to cultural disenfranchisement in which a social group identity or status is not valued or is seen as less worthy. This is the opposite of "normalization," or making something natural. Whereas a marginalized identity is at the periphery, a normalized identity is at the center. The dual process of normalization/marginalization creates both marginalized and normalized groups. According to Gayle Rubin (1993), queers are scapegoats on whom the dominant (centered) group unleashes their moral panic and insecurity, simultaneously normalizing the dominant group's experience. Marginalization is also used to distinguish the "culture (value) war" from other battlefields (Gamson, 1995). In the economic realm, one is alienated, and in the political realm, one is disenfranchised. I distinguish among these three to avoid obfuscating the different dimensions in which battles are fought. For example, African Americans may have gained political freedom via the Civil Rights Act of 1964 but they are still marginalized by our racist culture that propagates racial stereotyping and racial profiling. 
In sum, Ô-Môi is a case study on the everyday identity politics that support and normalize queer immigrant experiences in the face of racism, sexism, and heterosexism. By examining patterns of identity work and the factors influencing them, I offer insights into how the everyday identity politics and practices of marginalized people can resist hegemony or reinforce hegemony.

\section{BACKGROUND ON GROUP AND ENTRÉE}

"Ô-môi" is a tropical fruit in Viet Nam. Because of how it is consumed (by splitting the flesh and sucking the nectar), it has also been a slang term for lesbians. It was popularly used in the late 1960s to mid-1970s in Saigon, now Ho Chi Minh City. About twenty years after the fall of Saigon and the mass exodus of Vietnamese to the U.S., "ô-môi" re-emerged in Southern California as the name for a newly found support network of Vietnamese lesbians, bisexual women, and female-to-male transgenders. In the summer of 1995, a group of Vietnamese American queer females decided to adopt the word "Ô-Mối" as its name. This group of queer females reclaimed not only a Vietnamese history that included queers, but also a queer, cultural heritage that was specifically Vietnamese, thus dispelling the myths that homosexuality was a Western phenomenon and that Vietnamese queers were nonexistent.

Three Vietnamese immigrant women founded Ô-Môi in 1994. My-Linh was a college graduate who came out in college in the context of queer political organizing on campus. Thanh-Thu was a straight-identified woman until she met a group of gay Vietnamese men, who gave her the support to explore other sexual possibilities; she eventually came out as bisexual. Van was a non-identified social service provider in the Vietnamese community of Orange County. She had recently been assigned to work on an AIDS program, and part of her task was to create a steering committee of Vietnamese community members. Thanh-Thu and My-Linh were Van's co-workers and helped Van in recruiting members for this steering committee. They quickly realized that there was a visible and accessible gay Vietnamese men's organization called GVA (Gay Vietnamese Alliance) but there was no organization specifically for Vietnamese lesbians. Thanh-Thu, with the encouragement of GVA leaders, thought it was time to organize a women's group similar to GVA. Her intention, though, was to create a social setting in which Vietnamese women could meet. My-Linh, whose politics were more radical, envisioned a political organization that would fight against racism, sexism, and homophobia. She saw the organization as a "safe space" for queer Vietnamese women and also a source for political consciousness raising and mobilization with other queer women of color. Van, who never identified her sexuality, supported a queer women's group to facilitate her AIDS program. According to My-Linh, however, Van did not understand queer Vietnamese issues and appeared not to be invested in the group. Indeed, Van left the group early in its development. Apparently, the 
group's frequent teasing and questioning of her sexuality made the environment too uncomfortable for her to continue in it. Unfortunately, Van left before I could interview her about her goals (social vs. political) for the group. The two remaining leaders and cofounders of Ô-Môi set two different currents for the direction of the group.

Members were recruited through word of mouth. Their age range was 20 to 43 , with the majority in their mid-20s to mid-30s. I was recruited through Thanh-Thu, who knew a straight friend of mine. At the time, I was just coming out and knew of no Vietnamese lesbians. Other recruits included women who had been in long-term lesbian relationships and had similar couple friends, and women who had newly come out and had marginal contact with GVA. At the first few meetings, when the group was made up of only six members, two members came out as non-woman-identified. We discussed that they must be female-to-male transgender. Not understanding much about transgender issues and wanting to be inclusive as well as to increase membership, we voted that the group include FTM transgenders as well as lesbians and bisexual women. At a later meeting, the group of then 20 + queer women and two FTM men voted to refer to ourselves by the Vietnamese term, "Ô-Môi." We defined our basis of commonality as being Vietnamese, female, and attracted to women.

When asked why they wanted to join Ô-Môi, most members answered that they wanted queer, female, and ethnic/racial support. A Vietnamese female-to-male transgender explained,

In an Asian queer group, people understand where I come from when I talk about family problems. With the general white, queer group, I would have to spend a significant amount of time just explaining myself. So I prefer being with others like me. It's a bonus that Ô-Môi is Vietnamese.

Many members cited cultural commonality as the reason for joining. When asked how this would be more comfortable than being in a mainstream organization-i.e., predominantly white queer-one member explained, "You guys kinda know the Vietnamese background ... so you understand and have sympathy for me if I can't go out late or stuff my parents don't want me to say or do." In contrast, she had to justify herself to non-Asian queers. She elaborated, "Well, they'll tell me 'it's your life, why don't you control it rather than let your parents control it.' And I don't want to have to go through that." The pressure to come out to one's parents and fight for one's choice instead of sacrificing it for the collective good of the family was a Western model that, according to many Ô-Môi members, negated family duties and cultural obligations. Members needed this cultural support.

Related to cultural support, members explained that having a common language made it easier to communicate, especially for immigrants who had not 
mastered English. Ethnic commonality also meant a set of assumptions as a new lesbian member elucidated:

I want to find out more about the organization and to make friends with other Vietnamese and to find a Vietnamese girlfriend ... we Vietnamese are more emotionally connected (sentimental) and speaking the same language makes it easier to connect and develop a strong relationship. [Translated]

Because of the pervasive force of assimilation, joining an ethnic organization was a way to maintain one's language and cultural practices. The assumption was that such ethnic groups would celebrate ethnic values and language that would counter the assimilation pressure.

\section{Reflexivity}

When I first joined Ô-Môi, it was a journey of self-exploration. I had just entered graduate school and my research project was leading towards multiple identity issues from an interactionist perspective. Learning more about critical ethnography and extended case study, I wanted to use Ô-Môi for a case study on multiple identity issues. When I became coordinator of the group, I gained a rare access to the making of a queer, ethnic, gendered organization. I decided to use the research as a needs assessment for Ô-Môi. From 32 interviews with members and three years of participant-observation, I compiled and analyzed data from interactions during social gatherings, planning meetings, and listserv discussions. This study was also a means for the voices of a marginalized group to reach a wider audience.

This paper uses a portion of my dissertation data to examine everyday identity work at Ô-Môi as hegemonic and counterhegemonic processes. I discuss how the organizational structure, members' class statuses, sexual/gender identities and politics, and members' racial/ethnic, gender and sexual discourses interacted to create patterns of identity work that centered the experiences of lesbian, bilingual Vietnamese American women while marginalizing transgender, bisexual and monolingual members.

\section{DECONSTRUCTING AND CONSTRUCTING HIERARCHIES}

\section{Organizational Structure and Limitations}

Ô-Môi was originally conceived as a volunteer, self-help group. Ô-Môi's co-founders wanted to create a "safe space" for queer Vietnamese females. The founders had resources as social service providers to supply meeting venues and clerical work for the organizing and recording of meetings. The group 
was maintained and run in accordance with members' interests and availability. New leaders with resources emerged to replace old ones to perform similar tasks. As a support group, Ô-Môi established regular meetings to gather socially and to organize bigger events, such as camping trips, dinner banquets, and Pride March. Mostly, Ô-Môi operated as a place for members to meet and support each other. The lively presence of other Vietnamese queers helped members to feel less isolated and alone.

To organize a meeting required a space that would be "safe" for members to gather. Meeting at a member's house was considered a safer setting than an agency. Who was out and who had the resources to host at their home became limiting factors of Ô-Môi organizing. In addition, having members who were spread out in Los Angeles, Orange, Ventura, and Riverside Counties and Santa Barbara could mean an hour to three hours drive to a meeting. The geographic dispersion of members thus also limited membership participation. Time and money were required for social outings. Some members did not have the luxury of spending $\$ 20-40$ to go out to a club, an event that might require them to drive one hour from Orange County to West Hollywood and another hour back. Other members had weekend work or family obligations such as caring for young children and curfews that were barriers to attending many of Ô-Môi functions. In the next section, I discuss in greater detail the issues that limited participation and resulted in a disproportionate representation of types of members and their related concerns.

\section{Working Class versus Professional and Middle Class Participation}

Working class members had a difficult time attending Ô-Môi functions. Many worked at least two jobs and either six or seven days a week. Their hard earned money was carefully weighed against expenses of weekly clubbing. Even small gatherings such as a potluck required time and money. The schedules of working-class members were also less flexible than those of graduate students or white-collar workers with nine-to-five jobs. Driving to meetings all over Los Angeles and Orange Counties also required a decent car, which some members did not own.

A member-run group thus became an organization for a selective group of members. Middle-class and professional members, because of their social locations, had an easier time attending Ô-Môi meetings and events, ensuring their concerns and interests were addressed at planning meetings. Graduate and undergraduate students, although not yet earning middle-class income, were also frequent participants because of their more flexible schedules. Consequently, these students and other professional members became the dominant participants and voices of Ô-Môi. In addition, having more managerial skills and greater access to clerical resources, professional members more often ended up in leadership positions. In sum, professionals and middle-class members, who were frequent participants because of their class positions, 
helped define the types of group activities and concerns, which had the impact of deterring the participation of working-class members who were unable to afford middle-class queer lifestyles.

\section{Personal Politics and Leadership}

Besides organizational limitations that led to dominance of some members' participation and interests, the politics of members, especially leaders, also played a major role in the group's orientation and direction. There were two currents in Ô-Môi's direction: one was to be a social group and the other was to be a political force. Co-founder Thanh-Thu started the group because she wanted, first and foremost, a space for people to meet:

I just wanted a place where the women can come and be themselves, to have fun. I really didn't have a political agenda behind it. ... My original thought was just to provide a vehicle for people to come together. Provide a place, yeah, a place to give reasons for people to be together. To get to know one another.

Thanh-Thu wanted a social support group for isolated Vietnamese lesbians to meet and expand their friendship circles. Thanh-Thu saw Ô-Môi as a training ground to help members cope with their marginalized statuses through identity affirmation. In short, she subscribed to an identity politics that Steven Seidman (1996) would call an affirmative politics.

In contrast, co-founder My-Linh subscribed to a queer and deconstructive politics that challenged the status quo. My-Linh wanted to galvanize a group of queer Vietnamese females for political mobilization to confront different forms of oppression. She writes,

I wanted to be part of a network of women, especially women who challenged mainstream white America [on racism] as well as Vietnamese America [on heterosexism and homophobia]. And I wanted a space just for us, where we didn't have to worry about accommodating whites/males/straight people. I wanted to be a part of a group of queer Vietnamese women (then FTMs) who were creating a community that would validate, empower, and support each other.

In addition to identity affirmation, My-Linh wanted members to become politically progressive in fighting inequality. Unfortunately for My-Linh, the group never moved far towards this goal with its growing membership and diversity of politics.

Differences in expectations and visions of the group were manifested in divergent focuses on group activities. They forced members to compromise and alternate activities so that their minimal political and social expectations were 
met. The debate over a safe space illustrates this clash of visions. From one perspective, the group was organized around specific, shared identities and those who did not share these commonalities were not considered members. According to the other perspective, the group was a social network to support multiply marginalized members and their friends who might not share such identities. Consequently, the group compromised to alternate between an "open" meeting for members and friends and a "closed" meeting for members only.

An incident over an e-mail discussion is another example of this clash in visions. A member had posted a joke on the group's listserv. A handful of members found it offensive and racist, and responded by admonishing the original sender. Others didn't understand why everyone had to be so "politically correct" because it made the group "so serious" and restrictive. "Why be a support group if you censor people?" was one dissenting comment to the listserv facilitator. As a support group, it was believed that people should feel free to express themselves here, but this type of policing made the group censorious and less supportive or understanding of members. Politically progressive members, however, felt the group should not tolerate racist, sexist behaviors and attitudes. As one politically progressive member put it, "If it weren't for Ô-Môi, I would not be friends with some of these women." She did not share some of these members' politics or visions.

Another member assessed the group's diversity as both its strength and its weakness. She was grateful for the opportunity to learn more about transgenderism and the struggles of working class members. Yet, she found different perspectives kept the group from moving forward with a common agenda and vision. In the end, the extremes of neither camp won as Ô-Môi continued to grow and change in membership diversity, which continued to shape and reshape these two political currents.

\section{The Lesbian Majority and Normalization}

Support comes in many different forms. For some members, the mere presence of others provides support by validating that one is not alone. For other members, support means hearing statements that confirm and affirm one's sense of self as a sexual and ethnic minority female. The doing of ethnic and queer identity among members affirms these otherwise invisible and marginal identities. By speaking and sharing their experiences, members feel they become a part of a larger community of marginalized individuals who can understand and know where they are coming from so that they do not feel a need to have to explain themselves.

Normalization and marginalization are two sides of the same coin because the process of normalization also marginalizes (Ault, 1996; Pfohl, 1993). Research on deviant communities has shown that while the marginalized members may come together to normalize their experiences as deviant "Others," 
they do not escape marginalizing one another in the process as is evident in examples of how racial minorities and women are sometimes treated within the queer community and how some gays and lesbians treat other sexual minorities (Anzaldùa, 1990; Rubin, 1993).

Marginalized and isolated by the straight world, people joined Ô-Môi to be connected and affirmed. Their commonality allowed them to establish rapport with one another. As the majority of Ô-Môi members were lesbian-identified Vietnamese, members were generally assumed to be lesbians and Vietnamese; lesbian identity work dominated interactions. This assumed common bond was played out in everyday interactions where members asserted their commonality as "lesbians" or "queer Viet womyn." When transgender and bisexual members or their advocates raised issues of difference, a second attempt at establishing commonality led to identifying the group as a group of "females of Vietnamese heritage who were attracted to other females." This specification still rendered the marginality of transgender and bisexual experiences by ignoring differences.

This identity work stressing sameness among members helped to create a sense of "groupness" and cohesion. In a diverse group that was trying to coalesce, this practical essentialism, assuming sameness among diverse members, achieved the goal of creating unity. Members used the rhetoric of identity politics with ease to draw boundaries between members and non-members, making Ô-Môi a unique space for queer Vietnamese females. For example, doing queer identity work was a way to achieve unity among the diverse gender-identified and sexuality-identified individuals at Ô-Môi. This level of queer solidarity was a remarkable accomplishment in a society where boundaries were more narrowly defined. On the other hand, the form of queer solidarity at Ô-Môi centered lesbian experiences and only supported bisexual and transgender members marginally.

\section{Discourse on Homosexuality/Bisexuality}

The majority of members identified as lesbian. This led to the dominance of lesbian identity work that privileged lesbian experiences over those of bisexual women and FTM transgenders. At the same time, the presence of assertive bi women and FTM transgenders and their allies reminded lesbian members of Ô-Môi's diversity and its need to be inclusive of the numerical minority. Yet, the discourse the majority used to normalize their experiences was monosexually biased and constructed bisexuality in a negative light. As one lesbian put it, "I think they [bisexual women] are confused." Using discourse that naturalized homosexuality and heterosexuality (monosexuality), lesbian members often thought in binary terms that one was either gay or straight, with no other alternatives. One lesbian member asked a bi woman, who had not been very active in the group, "So are you going straight?" In this lesbian member's view, the bi 
woman could not be living out her bisexuality but was choosing to become straight to inherit straight privileges.

In this lesbian-majority setting, issues that were raised centered on concerns of lesbians or "women-loving-women." Bisexual women's concerns-their interest in and relationships with men-were not topics that affected the lesbian members. Often, when discussions about bi members and their male relationships arose, they had to do with how a member had dumped her girlfriend for a man. According to bi-identified Thanh-Thu, "the whole Ô-Môi experience was ... willing to forego my bi-ness and be a lesbian." As a co-founder of the group, she felt that she needed to establish her credentials as a female-loving-woman since that was the fundamental commonality for all lesbian, bisexual and transgender members. Thanh-Thu confessed, "The entire time I was in Ô-Môi, ... everything I did, everything my mannerism, everything was trying to be as lesbian as I could." I asked her why, and she explained:

[B]ecause I wanted people to maybe believe in me enough so that they would continue the group.... I lived the lesbian life. That entire experience, from the point that I met Ted, really, was when I started living it, even though I hadn't even thought that I even loved women, I lived that life, because I wanted to know what it was like to be queer. So, until, I guess, until I broke off my organizing experience with Ô-Môi, then I started exploring, what does bisexuality mean to me. Now that I'm not in Ô-Môi any more, now I don't have to pretend.

Whilst in Ô-Môi, bisexually identified members had to suppress their attraction towards men and play the "good lesbian" role. No bi-identified members ever shared with the large group their relationships with men, let alone boasted of their success. When they were dating men, bi women's loyalties were suspect, and they were questioned as to whether they had "turned straight." A number of bi women eventually left the group to be with men. Incongruously, lesbian members felt free to boast or complain about their relationships with other women and in so doing felt supported in these group interactions, where their lesbian experience was validated. The only bi women who were more comfortable and outspoken about their bi identity were those who were in a relationship with a woman and, therefore, did not risk being questioned regarding their loyalty. Their commonality with other women was secured until they threatened that bond by expressing interest in men, a sign of their betrayal to their lesbian sisters. The group, being constructed as a female-centered group, offered little room to negotiate a more complete bi experience. The status of bi-identified women in O-Môi was thus tenuous, with jokes such as referring to bi women as "bye-bye girls" and pervasive assumptions about how a bi woman would leave her girlfriend for a man, because a woman partner was not enough for her. For most lesbian members, "bi" meant "both, simultaneously" and, therefore, evoked the bitter vision of a bi woman's relationship with her 
boyfriend/husband and a side lesbian lover. This symbolized a threat to lesbians' happiness. Subsequently, women in the group began to refer to it as a "queer women's group" rather than a "lesbian and bi women's group." The word "queer" in this sense masked the difference and suspicion between lesbian and bi women and united them as "queer women."

\section{Discourse on (Trans) genderism}

How Ô-Môi changed from a women's group to include specifically FTM transgender was a hard and long process of negotiation and a naïve attempt at inclusion. The founders wanted a women's group. Unexpectedly, at the third meeting, a member came out as "not identifying as a woman," which was understood to mean transgender. Needing more members, the original members decided at that moment to expand the group to include transgenders.

The inclusion of transgenders in our subtitle did not translate to full support and consideration of transgender issues, however. Members slipped $80 \%$ of the time (based on e-mail discussions and my field notes of meetings) in referring to the group as a women's group, which, ironically, was meant to unite members. For our FTM transgender members, being referred to and treated as men was a sign of validation while being assumed to be or referred to as women had the opposite effect. Ben told us that whenever people let him open doors for them or asked him to carry heavy boxes, he experienced these moments as "cheap therapy." In contrast, a stranger could make Ben depressed all day just by referring to him as a woman. It was worse when this happened at Ô-Môi gatherings where members were expected to be more sympathetic to issues of marginalization. Being in Ô-Môi, where the majority identified as "women," Ben felt a bit uneasy meeting members he had not yet met, because he knew they would assume that he was "a lesbian who looks and acts like a man but still identifies as a woman." Ben did not want to be attributed with anything female. In fact, he asserted that he would only date straight women who saw him as a man and would not date lesbians who thought of him as a woman. So, Ô-Môi served as a site for lesbians to meet and date other women-loving women; it did not serve the same function for transgenders.

Given the predominance of lesbians in the group, organizers often forgot to include transgender needs and concerns in organizing events and group discussions. In little ways, transgenders felt excluded. One transman stated, "I don't think you guys really support transgenders because you always talk about Ô-Môi as a women's group."

To rectify this situation, progressive members pushed for a workshop to teach each other about transgender issues. This helped many to understand a little more about transgenders. At the same time, it also raised issues about the commonalities among members, because we were no longer all women. We now had women and men. Questions arose about whether we should include all transgenders or just female-to-male (FTM) transgenders. Given that the group 
had only had FTM transgenders, we decided that we would only specify this group and would reopen the discussion if other trans individuals came to Ô-Môi. Ben theorized that being born and treated as a girl/woman created a different experience for all women and FTM transgenders than being socialized as a boy/man did for MTF transgenders. We decided that FTM transgenders were members until they fully transitioned (getting hormonal treatment, breast removal, and sex-change operation). Following the last stage, it was assumed that FTM transsexuals would take on the straight male lifestyle and within Ô-Môi would transition from in status from "member" to "supporter." Deductively, Ô-Môi members were those with female genitalia who desired women. Comments about FTMs who identified as gay and desired men were dismissed as hypothetical. Since all our FTM identified as straight men who desire women, it was concluded that our commonalities were having female genitalia and desiring women.

In sum, when members talked about the group, they referred to it as a "womyn's group." "Transgender" was often added as an afterthought, if at all. When transgenders were considered, it was with little understanding of transgenderism, as evidenced in how members continued to refer to FTM members as women and "she" or "her" or "whatever." A significant number of lesbians saw transgenders as "lesbians who hate their bodies." At these moments, either FTM members or the more politically progressive members would correct the erroneous language and perception of the speaker. Often, an inclusive term such as "queer Vietnamese" was used to refer to the group instead of "queer women's group." Because lesbian issues dominated the agenda of Ô-Môi, consciousness of transgenders as core members was rare for the majority of queer women members. In short, only politically radical members and the few transgender-identified members of Ô-Môi used the language of inclusion. Transgenders in Ô-Môi felt more support for their ethnicity than their transgenderism. They joined mainstream FTM transgender groups to learn about available resources in transitioning as they could not rely on the lesbian majority of Ô-Môi to provide them with that information. Conversely, women who were questioning their possible lesbianism had access to a wealth of resources on lesbianism from the visible lesbian members.

\section{Discourse on Vietnamese-ness}

The ethnicization process was both similar to and different from the racialization process. As immigrants coming to a new country and being racialized as a racial minority, Vietnamese quickly learned that they are not seen and treated as "American" but as "Oriental" or "Asian" and were lumped with other Asian American groups. They also learned that their unique cultural heritage was not necessarily valued or congruous with the ways of the dominant U.S. culture. Furthermore, they quickly learned about the importance of social capital in their ethnic community. Like other immigrants who faced barriers, Vietnam- 
ese saw their ethnic identity become more salient in their struggle to make it in the U.S. (Portes \& Rumbaut, 1990; Zhou, 2000). Becoming racial minorities and seeing the importance of maintaining ethnic ties, Vietnamese Americans further found themselves in a unique location as "refugees" with drastically different migration experiences than immigrants. This unique ethnic experience as Vietnamese refugees needed validation.

The force of assimilation (loss of language, values and customs) threatened the bond among co-ethnics to their homeland and children. Vietnamese refugees, like other ethnic immigrants, created ethnic organizations (e.g., language schools, religious organizations) to maintain and affirm their cultural heritage and provide emotional and social support (Min, 2000; Zhou, 2000). These U.S.-made organizations, however, not only maintained cultural heritage but also redefined it because of contextual limitations of a new setting.

Like other ethnic organizations that attempt to hold onto the culture and language that asserted and affirmed their ethnic identity, Ô-Môi also attempted to redefine Vietnamese-ness. Its version included queer Vietnamese that mainstream Vietnamese organizations tended to exclude. Because the mainstream Vietnamese American community constructed Vietnamese-ness as straight, Ô-Môi countered such heterosexist force by re-evaluating certain historic Vietnamese figures as possibly queer. The group's name was an exemplar of this rereading of Vietnamese history and of asserting a queer Vietnamese existence and "herstory" for themselves. The next case also illustrated this imperative to synthesize ethnic and queer identities.

Ethnic Authentication. When My-Le came out to her parents they told her that she had become Americanized. In Vietnam, she would not be gay. Her parents, her main source of ethnic authentication, saw a dichotomy between being Vietnamese and being queer. Hence, My-Le always felt her Vietnamese and queer worlds were in conflict. Finding Ô-Môi, however, helped to authenticate her ethnic identity and synthesize her queer and Vietnamese identities. Ô-Môi helped bridge the gap for her; she could claim both queerness and Vietnamese-ness because now there were other Vietnamese queers to validate her. Particularly because her Vietnamese language ability was limited, My-Le also felt insecure about her Vietnamese identity. But, having met a diverse group of Vietnamese queers with varied Vietnamese proficiency, My-Le could see now that her "inadequacy" was a normal part of Vietnamese American experiences.

English/Vietnamese Monolingual as Marginal Members. Originally, Ô-Môi was founded to support particularly Vietnamese monolinguals. Ironically, the majority of members in Ô-Môi communicated with each other in English. Leaders of Ô-Môi were those who were comfortable with English as their primary language but could also communicate in Vietnamese, at least rudimentarily. When members gathered for an event, the primary language spoken was English. Viet-glish (Vietnamese words interspersed in English) 
was spoken now and then as a way of doing Vietnamese identity work. Only members who spoke proficient Vietnamese would speak to each other in Vietnamese. When the more acculturated members attempted to speak Vietnamese to others, it was usually because they were consciously practicing Vietnamese, not because they were more comfortable speaking Vietnamese. Given the organizers' limited Vietnamese proficiency, when they created newsletters and flyers, they wrote in English and they needed to translate them into Vietnamese. Sometimes, when there was insufficient time for translation, Ô-Môi members received Ô-Môi newsletters and flyers in English only. There was usually a line in Viet-glish apologizing for the lack of translation and asking that Vietnamese-only readers call the organizers for more details.

When Ô-Môi discussions went online, the conversations among members were strictly in English, because those who participated were comfortable with English as their language of expression. When new members who were more comfortable with Vietnamese joined the listserv, they started posting messages in Vietnamese. Nhi-Hang initiated this practice with a Vietnamese poem. Others responded in Vietnamese poetic forms. Oan and Carmen posted messages asking for a translation. Tho translated the first poem for Oan and Carmen. Then, we were showered with new poems from excited members who finally got a chance to amuse themselves in Vietnamese. It was then that Genie shared her pain of not understanding Vietnamese with us.

I am very sad today. I'm sure you have no idea why but please give me a few minutes of your time to explain why. I just received a bunch of emails (ten to be exact) and I didn't understand a single one. I guess to preface this I have to mention that I am truly honored to be a part of omoi because I honestly thought I was some kind of aberration, a freak, the only one. I love that I have been able to feel safe and welcome in a queer organization. However, I have always felt in between, like I never really fit in anywhere. I guess being a biracial and bisexual woman, my multiple identities intersect in a place that Gloria Anzaldua refers to as the borderlands, that grey area in between.

She suggested that, "out of respect for our sisters who may not speak Vietnamese," members provide English translation so that "people do not feel alienated, left out, un-Vietnamese, stupid or whatever."

A few members apologized for not including Genie and other non-Vietnamese readers in the conversations and attempted to translate future messages. I expressed sympathy for Genie, but as a moderator, I reminded her that not all members could read and write English proficiently just as some were not proficient in Vietnamese. To have equality for everyone, every message must be posted bilingually, and this was impossible for members 
with limited abilities. I concluded that this translation task was dependent on those who were capable and willing.

My-Linh responded that if we were going to translate anything, it should be English to Vietnamese, because most of the postings on this listserv had been in English. It was usually the Vietnamese translation that was left out. She elaborated:

Most of our days are spent talking in English, and those that don't understand English have had to deal with it for many years. I don't think it is right to ridicule or put down Vietnamese and Vietnamese Americans who don't speak Vietnamese, but I don't think that there is anything wrong with posting Vietnamese-only messages on this egroup. This is not a practice of exclusion, it is a practice of exerting pride and celebrating being queer in a language that doesn't often acknowledge and most definitely doesn't support our queer identity. It's a staking out of territory in the Vietnamese community-to state that we ARE part of the Vietnamese community, that Vietnamese queers have always been a part of the community.

My-Linh reminded us that one of the reasons why we started Ô-Môi was that there were not many spaces/places that cater to Vietnamese-speaking queers. Other queer API organizations were not meeting the needs of Vietnamese-speaking queers, hence, "we needed to be sensitive of that." She further reflected:

Even this conversation, it's all in English.... I also do not have access to Vietnamese-only postings, and I do not lament this lack of access. I celebrate it as a success of this egroups-we are beginning to be a resource and a mode of support for vnlbt's who do not want to "translate" their experiences. In a poem from "this bridge called my back," I think it was Gloria Anzaldua who wrote: "I am tired of being your bridge."

Although Ô-Môi was founded with the purpose of supporting Vietnamese American queer females, especially monolingual Vietnamese-speakers, the majority of members were not fluent in Vietnamese, and English was the dominant language. The majority of leaders of Ô-Môi were more proficient in English than Vietnamese, which created the situation in which English became the language of daily operation. As Ô-Môi gained more members who spoke more Vietnamese than English, the leaders needed to change their mode of operation to include the new members. Otherwise, Ô-Môi would be more of an organization for English-speaking Vietnamese Americans. The shift in activities to online discussion had opened more ways for Vietnamese-only speakers to participate, and this helped Ô-Môi to attract more members who were not proficient in English. This openness, however, threatened the norm of speaking English as evidenced in the previous case. However, Vietnamese monolingual members had to rely on the advocacy of bilingual 
members in negotiating for a space to speak Vietnamese only. While non-Vietnamese-speaking members might have felt alienated by this event, they could resort to English to file their complaints to the main organizers. In contrast, Vietnamese-only speakers did not participate in this debate. Given the composition of Ô-Môi, bilingual members benefited the most from these debates.

\section{CONCLUSION}

The paradox that Ô-Môi members have had to cope with was affirming the diversity of the group members at the same time as asserting commonality among members. In the process, certain differences were ignored. Given that the majority of members were lesbian and that the group's vocal base was lesbian-dominant, Ô-Môi often prioritized lesbian issues and concerns. Bisexual and transgender were then marginally supported.

I have shown how organizational structure, discourse resources and personal politics affected the types of identity work done at Ô-Môi. As a volunteer support group, Ô-Môi limited its membership participation to more professional and middle-class members. As a lesbian majority group, the discourses available to normalize their experiences were lesbian-focused and biased against bisexual and FTM transgender members.

The concept of "identity work" has helped us to see how identity was created and recreated through everyday action. Sometimes identity work reinforced hegemonic understandings of race, gender, sexuality and ethnicity. At other times, identity work challenged hegemony by renegotiating the meanings and relationships evoked by racial, sexual, gender and ethnic discourses. While the lesbian majority at Ô-Môi had created an environment conducive to the prevalence of lesbian identity work that prioritized lesbians' concerns over the concerns of bisexual and transgender members, we have also seen that members actively and creatively worked to establish commonality ("queer Vietnamese female group") to bond with and support one another. In addition, politically progressive members were conscious of creating an environment that was more inclusive of the needs of transgenders, bisexuals, monolinguals, and working class members. So long as these members continued to practice their everyday deconstructive politics, they kept Ô-Môi inclusive and free from restrictive discourses of membership closure. In this sense, identity work by Ô-Môi members could be seen as hegemonic or counterhegemonic practices of everyday identity politics. The examination of identity work at O-Môi provided us a glimpse into how gender and sexuality interplayed in the ethnicization process of becoming Vietnamese Americans. Technically, it was a process of becoming gendered and sexualized ethnic Americans in capitalist America. 


\section{REFERENCES}

Anzaldùa, G. (1990). Bridge, drawbridge, sandbar or island: Lesbians-of-color hacienda alianzas. In L. Albrecht \& R. M. Brewer (Eds.), Bridges of power: Women's multicultural alliances (pp. 216-231). Philadelphia: New Society Publishers.

Ault, A. (1996). The dilemma of identity: Bi women's negotiations. In S. Seidman (Ed.), Queer theory/sociology (pp. 311-330). Cambridge, MA: Blackwell.

Brubaker, R., \& Cooper, F. (2000). Beyond identity. Theory and Society, 29, 1-47.

Burawoy, M., Burton, A., Ferguson, A. A., \& Fox, K. J. (1991). Ethnography unbound: Power and resistance in modern metropolis. Berkeley, CA: University of California Press.

Butler, J. (1990). Gender trouble: Feminism and the subversion of identity. New York: Routledge.

Calhoun, C. (Ed.). (1994). Social theory and the politics of identity. Cambridge, MA: Blackwell.

Cheney, G. (1991). Rhetoric in an organizational society: Managing multiple identities. Columbia, SC: University of South Carolina Press.

Cohen, C. J. (1996). Contested membership: Black gay identities and the politics of AIDS. In S. Seidman (Ed.), Queer theory/sociology (pp. 362-394). Cambridge, MA: Blackwell.

Collins, P. H. (1990). Black feminist thought: Knowledge, consciousness, and the politics of empowerment (Vol. 2). New York: Routledge.

Dunn, R. G. (1998). Identity crises: A social critique of postmodernity. Minneapolis, MN: University of Minnesota Press.

Espiritu, Y. L. (1992). Asian American panethnicity: Bridging institutions and identities. Philadelphia: Temple University Press.

Esterberg, K. G. (1996). "A certain swagger when I walk": Performing lesbian identity. In S. Seidman (Ed.), Queer theory/sociology (pp. 259-279). Cambridge, MA: Blackwell.

Esterberg, K. G. (1997). Lesbian and bisexual identities: Constructing communities, constructing selves. Philadelphia: Temple University Press.

Gagne, P., \& Tewksbury, R. (1998). Conformity pressures and gender resistance among transgendered individuals. Social Problems, 45(1), 81-101.

Gamson, J. (1995). Must identity movements self-destruct? A queer dilemma. Social Problems, 42(3), 390-407.

Giddens, A. (1992). The transformation of intimacy: Sexuality, love and eroticism in modern societies. Stanford, CA: Stanford University Press.

Gleason, P. (1983). Identifying identity: A semantic history. Journal of American History, 69, 910-931.

Gubrium, J. F., \& Holstein, J. A. (2001). Introduction: Trying times, troubled selves. In J. F. Gubrium \& J. A. Holstein (Eds.), Institutional selves: Troubled identities in a postmodern world (pp. 1-20). New York: Oxford University Press.

hooks, b. (1984). Feminist theory from margin to center. Boston: South End Press.

Masequesmay, G. (2000). Everyday identity work at an Asian Pacific AIDS organization. In M. F. Manalansan (Ed.), Cultural compass: Ethnographic explorations of Asian America. Philadelphia: Temple University Press. 
Masequesmay, G. (2001). Becoming queer and Vietnamese American: Negotiating multiple identities in an ethnic support group of lesbians, bisexual women and female-to-male transgenders. Unpublished doctoral dissertation, University of California, Los Angeles.

Min, P. G. (2000). The structure and social functions of Korean immigrant churches in the United States. In M. Zhou \& J. V. Gatewood (Eds.), Contemporary Asian America: A multidisciplinary reader (pp. 372-391). New York: New York University Press.

Omi, M., \& Winant, H. (1994). Racial formation in the United States from the 1960s to the 1990s (2nd ed.). New York: Routledge.

Pfohl, S. (1994). Images of deviance and social control: A sociological history (2nd ed.). New York: McGraw-Hill.

Portes, A., \& Rumbaut, R. G. (1990). Immigrant America: A portrait. Berkeley, CA: University of California Press.

Rubin, G. S. (1993). Thinking sex: Notes for a radical theory of the politics of sexuality. In H. Abelove, M. A. Barale, \& D. M. Halperin (Eds.), The lesbian and gay studies reader (pp. 3-44). New York: Routledge.

Rust, P. (1996). Sexual identity and bisexual identities: The struggle for self-description in a changing sexual landscape. In B. Beemyn \& M. Eliason (Eds.), Queer studies (pp. 64-86). New York: New York University Press.

Seidman, S. (1996). Introduction. In S. Seidman (Ed.), Queer Theory/Sociology (pp. 1-29). Cambridge, MA: Blackwell.

Simmel, G. (1988). The metropolis and mental life. In R. L. Warren \& L. Lyon (Eds.), New perspectives on the American community (pp. 17-25). Belmont, CA: Wadsworth.

Taylor, V., \& Whittier, N. E. (1992). Collective identity in social movement communities: Lesbian feminist mobilization. In A. D. Morris \& C. M. Mueller (Eds.), Frontiers in social movement theory (pp. 104-129). New Haven, CT: Yale University Press.

Waldinger, R., \& Bozorgmehr, M. (Eds.). (1996). Ethnic Los Angeles. New York: Russell Sage Foundation.

Wat, E. C. (2002). The making of a gay Asian community: An oral history of pre-AIDS Los Angeles. Lanham, MD: Rowman \& Littlefield.

West, C., \& Zimmerman, D. (1987). Doing gender. Gender \& Society, 1(2), 125-151.

Wittig, M. (1992). The straight mind and other essays. Boston: Beacon Press.

Zhou, M. (2000). Social capital in Chinatown: The role of community-based organizations and families in the adaptation of the younger generation. In M. Zhou \& J. V. Gatewood (Eds.), Contemporary Asian America: A multidisciplinary reader (pp. 315-335). New York: New York University Press. 